\title{
5
}

\section{Artisanal gold-rush mining and frontier democracy: Juxtaposing experiences in America, Australia, Africa and Asia}

\section{Deborah Fahy Bryceson}

Gold rushes dramatically heighten people's expectations of the future. Not all societies value gold, but in those where gold is viewed as a source of wealth accumulation, adornment and enduring economic value, news of the discovery of gold is irresistibly enticing for many. Most of those who succumb have no previous mining experience, and unwittingly enter an occupational transformation with unpredictable outcomes. The compulsive force of the gold rush phenomenon rests on mounting hype and hope of both local and migrant populations.

The nineteenth-century gold rushes of California and Australia gave rise to a rich and varied literature based on government record keeping, journalist accounts and miners' personal letters home, memoirs and diaries. By contrast, in our twenty-first century of instantaneous communication by cell phone and internet, gold rushes may generate media and academic interest after a lapse of time, but on-the-spot empirical accounts of events and activities of participants, be they miners, residents of the mining settlement or officials, are relatively negligible. ${ }^{1}$

1 There are notable exceptions; for example, the African case studies of Werthmann $(2000,2003$, 2010) and Grätz (2002, 2010, 2013). 
'Gold fever' is portrayed as a contagion affecting growing numbers of people who irrationally ignore the hardships, dangers and possibility of failure, keen to try their luck at catapulting into a more remunerative livelihood and better life. In effect, gold rushes are high-risk journeys into the unknown, with a strong possibility of disconnection between ends and means; the mirage that the individual sees on the future horizon as opposed to miners' meagre means to realise their goals given their lack of mining skill and the unpredictability of conditions at the mining site.

In their quest, what stands out is the individual's intent to succeed as a miner largely through learning while doing. The individual embarks on a process of becoming an artisanal miner through skill acquisition, economic exchange, psychological orientation and social positioning at the labour site, and gains a sense of proficiency and occupational professionalism through persistent work and collegial support (Bryceson 2010). An artisanal gold miner is self-propelled from the initial decision to migrate to a mineral site, arriving at the work site to begin an on-site apprenticeship and a mining career that entails material hardships and technical difficulties, and the inevitability of mineral depletion over time (Bryceson and Jønsson 2014). Before nineteenth-century mass artisanal gold-rush mining, gold was usually produced within tied labour relations of slavery, bonded labour or tribal tribute obligations that then formed the production base for long-distance commodity chains, involving a series of local middlemen and foreign merchants. Gold miners were locationally circumscribed and subject to tribal or other localised controls and exactions, with little awareness of the gold commodity chain that they supplied.

I argue in this chapter that gold rushes since the nineteenth century, involving individualised, highly mobile artisanal gold miners, may encourage the evolution of frontier democracy, depending on the extent to which hierarchically organised labour circumstances do not pose a constraint.

At the outset, some definitions are in order. 'Artisanal mining' is labourintensive mineral extraction with limited capital investment using basic tools, manual devices or simple portable machinery (Bryceson and Jønsson 2014). ${ }^{2}$ I use the term 'artisanal mining frontier democracy' to refer to miners' independent exercise of agency in the pursuit of their

2 It should be noted that hard-rock extraction worldwide tends to be performed by men, while women and sometimes children are more likely to be found panning, processing the hard rock, reworking tailings or working in the service sector of the mining settlement. 
mining activities; free association amongst people from various localities, occupations and class backgrounds who are focused on the artisanal extraction of gold, with scope for collective self-governance and political activity in furtherance of their mining interests. ${ }^{3}$

There are three essential conditions of existence for artisanal frontier democracy. First, miners voluntarily enter and exit artisanal mining sites on a relatively egalitarian basis. Second, working together, they assert a strong collective identity as artisanal miners in the process of acquiring skills and evolving shared professional norms and ethics. Third, they mine in nation-states where they have scope to devise the modus operandi of their work relations and mineral-access rights consensually on a trial-anderror basis (Bryceson and Geenen 2016).

Increasing numbers of people worldwide appreciate gold's value as a consumption and investment good. Gold production has expanded over the past two decades of economic boom and bust, catalysing the appearance of large numbers of artisanal miners in long-established as well as new strike sites. Technological innovations have facilitated the spread of information about gold strikes. Many artisanal miners travel over long distances. What is significant in terms of the focus of this chapter is that some arrive at 'pure gold sites', metaphorically termed, where they have scope to be self-employed, rather than subject to waged, bonded or enslaved labour arrangements imposed by pre-existing property ownership and power structures. Untied, independent artisanal labourers, engaged in high stakes and hazardous work, are inclined to cooperate with one another for mutual benefit. Therein lies the foundational basis for frontier democracy.

This chapter chronologically considers the nineteenth-century experiences before turning to twentieth-century African and Asian gold-mining sites in Tanzania and Mongolia, where deagrarianisation has been a powerful catalyst to labour diversification (Bryceson 1999, 2002). I argue that gold rushes taking place globally during the last two centuries in varied cultures and historical contexts converge remarkably towards similar forms of economic and cultural organisation characterised by exceptionally hard work and hard play in challenging physical circumstances. But not all display the dynamic of frontier democracy. The fundamental question explored here is when, how and why frontier democracy arises in some

3 My use of the term 'frontier democracy' is centred on the notion of a labour, rather than land, frontier (Dumett 1998; Grätz 2013; Bryceson and Geenen 2016). 
places and not others. The following sections, based on secondary literature, are intended as a preliminary exploration of where and when this tendency is likely to occur.

\section{Nineteenth-century gold rush experiences}

\section{Forty-niner miners in California}

The voluminous literature on the California gold rush includes a wealth of personal memoirs of nineteenth-century gold rush participants' migration and settlement (see, for instance, US Library of Congress n.d.; Street 1851; Brown 1894; Canfield 1906; Holliday 2002). It is apparent that there is a recording bias towards nationals with middle-class origins (Clay and Jones 2008).

The discovery of gold at Sutter's Creek in California in January 1848 catalysed an avalanche of local in-migration to the area. According to Vaught (2007), the person most instrumental in spreading news of the discovery was a San Francisco entrepreneur who advertised gold-panning equipment, thereby alerting the general public in the city and countryside beyond. By the end of the year, the news had reached Washington DC. President James K. Polk announced California's gold riches to the nation on 5 December 1848, prompting a large westward demographic shift of young men from eastern and mid-western states to the country's new California territory over the next four years. The local newspaper, The San Francisco Californian, charted the influx from its outset:

It was the work of but a few weeks to bring almost the entire population of the territory together to pick up pieces of precious metal. In less than four months, the prospects and fate of Alta California had been revolutionised. Then, capital was in the hands of a few individuals engaged in trade and speculation; now labor has got the upper hand of capital, and the labouring men hold the great mass of wealth in the country-the gold. (The San Francisco Californian, 14 August 1848, cited in Rohrbough 1998: 7)

A couple of months later, a report in the London Times was sceptical about the rush and its effect:

The discovery of gold in the Sacramento ... has produced a confusion of rank and a startling degree of equality ... we must hear more of this El Dorado before we bestow upon it ... our serious consideration. (The Times, early November 1848, cited in Hocking 2006: 21) 
Discounting journalistic hyperbole, it is revealing that the California gold rush was immediately identified not only as a profitable opportunity, but one democratically open to able-bodied men. ${ }^{4}$ An estimated 40,000 'forty-niner' migrants made their way to the goldfields in 1849 (Vaught 2007).

The gold strike occurred soon after the United States had wrested Alta California away from Mexico in the Mexican-American war. This had been an unpopular war, criticised for its expense and the conquest of territory considered of little value for the United States. Hence, President Polk was eager to broadcast news of the California gold strike. At the time, Alta California, as it was called then, was a territory not a state, and was not subject to US federal law. What makes the California gold rush so iconic as a frontier experience is that incoming multi-ethnic miners faced a seeming 'free-for-all' arising from the legal hiatus in the transition from Mexican to American political control. The existing Mexican settlers in Alta California had not been aware of the gold's existence. State regulation of mineral extraction was absent, with no mining licence system ${ }^{5}$ or legal clarity about who the gold finds belonged to. California was quickly granted statehood in 1850 , but the precedent had been set. The fortyniner miners retained relatively unimpeded access to mining.

Local migrants from San Francisco and the surrounding countryside numbered approximately 5,000 by the end of 1849 . Thereafter, tens of thousands followed, coalescing to over 100,000 as migrants from western parts of the United States and others from the East Coast travelled overland or by boat around the Horn of South America or through the isthmus of Panama, disembarking and walking to the Pacific coast where they boarded a boat to California. Nicknamed 'argonauts', this surge of people populated the new American state in what was a territorially expanding nation. Over 90 per cent of the gold-rush migrants were male, under 30 and generally planned to return to their farms (Vaught 2007).

The first wave of migrants were mostly unskilled, focused on alluvial placer mining using simple technology, generally a shovel and pan. Rohrbough (1998: 12-13) observed, 'Open access to the gold in California seemed to represent the purest example of American economic democracy in

4 The stream of migrants was over 95 per cent male (Clay and Jones 2008).

5 Non-US nationals were charged a foreign diggers' tax, which included indigenous Hispanics, Europeans and later Chinese, giving American nationals a digging edge. 
the middle of the nineteenth century'. Miners worked on the general principle of 'finders keepers'. Shinn (1884, cited in Rawls 1999) argued that the miners devised a code of conduct that governed the mining camps. ${ }^{6}$ Individual panning gave way to use of a boxlike 'cradle' for sifting sediment that was optimally operated by four people.

As alluvial gold yields declined, digging commenced. A system of mine claims evolved consensually amongst miners, beginning with early placer rights based on discovery, rather than landed property rights. Miners were not allowed to hold more than one mining claim. Claims amounted to usufruct rights recognised and maintained by continuing labour input (McDowell 2013). The mounting numbers of the miners gave them not only a strong demographic presence, but also economic and political power.

Census and survey analysis during the California gold rush suggests that on average miners succeeded in gaining higher earnings relative to what they could have expected in their pre-rush residences. However, given the high cost of living driven by exorbitant food costs, their real earnings were disappointing. The average earnings of non-mining service sector providers, in fact, superseded those of miners (Clay and Jones 2008).

The duration of expansion of artisanal mining settlements was roughly six years. As surface gold deposits became depleted, environmentally destructive industrial hydraulic extraction methods were introduced to achieve large-scale hard-rock underground excavation, which required heavy investment in technology and technical training. Artisanal mining was increasingly sidelined. Having begun with placer mining open to large numbers of unskilled men seeking their fortune as individuals, largerscale capitalist mining operations took over (Douglass 2002).

During the gold rush's heyday, social levelling was visibly evident in the simple work clothing people wore, which downplayed the fact that the migrant stream encompassed a wide range of lower- and middle-class people. The mining camp population was an economically and socially diverse assembly that necessarily had to operate on a trusting basis, both

6 Royce (2002) challenged this interpretation as over-romantic and oblivious to miners' inhumane behaviour towards Native Americans and non-white migrants. 
to facilitate their work and also because carried large amounts of gold in their pockets due to the absence of banks. Conspicuous consumption, with the notable exception of alcohol, was generally avoided.

The gold rush climaxed by the mid-1850s, having involved an estimated 300,000 people. Cornford (1999) observed that it was one of the largest occupational migrations of labour in American history, with 4,000 migrant miners in 1848, growing to approximately 100,000 in 1852. By the end of the decade, the miners who remained were wage labourers rather than self-employed. The migration coincided with a period when smallholder agriculture was declining in the US. Most gold-rush miners returned to their home areas or moved on to new mining sites elsewhere, including Australia. Of those who stayed on, some made the transition to industrial mining, mostly as wage labourers, and in far fewer cases as capitalist investors, but the majority remaining in California started farming, notably wheat, or were absorbed into industrial and service activities, contributing to the state's non-mining development take-off (McCone and Orsi 1999).

\section{Australia's imperial gold finds in Victoria}

There were several parallels and linkages between the gold rushes in California and Victoria. Two generations after Europeans first settled in Australia, interest was kindled in the continent's mineral wealth. Relying on Blainey's (1964) detailed account of the Australian gold rush, its progression is outlined here.

Ironically, in the early 1850 s, significant numbers of Australians had set sail for California to mine gold, not realising they were leaving a gold-rich country. James Esmond, an Australian who had returned from Californian diggings, struck gold in Ballarat in July 1851. News of Ballarat and other finds were eagerly snapped up by the national press, triggering a national gold-rush migration. Gold had also been discovered in New South Wales further to the northeast. Amidst these gold discoveries, New South Wales was subdivided, creating Victoria as a new, separate colony in which Ballarat was located.

Issuing of mining licences commenced in the latter part of September 1851 in Victoria. Deposits of gold and silver were the designated property of the Crown. Victoria's goldfields were considered the richest in the world at the time, prompting the government to immediately proclaim Crown 
rights, ruling that it was illegal to search for gold without a licence. ${ }^{7}$ The government registered and regulated miners' activities through a licensing system that required a monthly payment of 30 shillings for a licence.

A succession of gold finds followed those of Ballarat, most notably in Bendigo. So many men made their way to the goldfields that labour shortages appeared in critical occupations-blacksmiths, sailors and civil servants. Nearby Melbourne experienced an acute shortage of men, while women gravitated to settlements in the hope of meeting and marrying a rich digger. In early 1852, news of the rich finds reached Europe, enticing adventure-seeking men to risk the hazards of a three-month sea journey from Europe to Australia. Tens of thousands arrived by boat. Foreigners began to outnumber Australians in the camps. The mining camps consisted of row after row of tents. Men from a wide array of occupations mined side by side. The most successful miners usually tended to be the physically strongest, rather than the best educated.

The cultural trappings of the virtually all-male population, earning aboveaverage incomes, veered towards laborious weekdays and with pleasureseeking, heavy drinking and liaising with prostitutes in ramshackle hotels on the weekend. Despite overcrowding and heavy drinking, the crime rate was not higher than in Australia generally, and a consensual moral economy existed at the diggings, where trust and morality were considered to exceed that prevailing elsewhere in the country.

In Victoria, miners were required to have and display their licence while working at all times. Miners who failed to produce a licence for police inspection faced a group of intimidating, armed constables and a fine of 40 shillings or seven days' imprisonment. The taxation system became a great source of irritation for miners. The presence of foreign miners-Irish, continental European and American-who had no political allegiance to the British Crown, contributed to the growing disgruntlement against licence fee enforcement. Miners greatly resented the legal imposition,

7 This ruling was immediately enforced, unlike in New South Wales where news of gold had attracted hundreds of men to panning and digging activity faster than the government could assert control over it. There were not enough police and soldiers to enforce the Crown's property rights, and the Governor of Australia informed London that it would be unrealistic and hazardous to prevent the incoming miners from their gold-rush search. A new Commissioner of Crown Lands for the gold district was appointed to set up the licensing system, settle disputes and provide justice in petty courts. However, as the gold rush spread to various scattered sites, miners often succeeded in avoiding fee payment in the more far-flung areas (Blainey 1964). 
particularly when they were asked to pay while down in a pit, necessitating their ascent, or when the tattered or water-damaged state of their licence was challenged (Keesing 1967). As the goldfields became depleted, the number of miners failing to find gold rose. One observer estimated that no more than 20 per cent of miners had made finds. Miners' monthly licence payments became difficult (Chandler 1990, cited in Hocking 2006: 126).

Political activism surged when the new Governor of Victoria, Sir Charles Hotham, was appointed. Soon after his arrival he reported to the Colonial Secretary:

no amount of military force at the disposal of Her Majesty's Government, can coerce the diggers, as the gold fields may be likened to a network of rabbit burrows. For miles, the holes adjoin each other, each is a fortification ... nowhere can four men move abreast, so that the soldier is powerless against the digger, who well armed, and sheltering himself by the earth thrown up about him, can easily pick off his opponent—by tact and management must these men be governed; amenable to reason, they are deaf to force ... (Hill 2010: 170) ${ }^{8}$

Only a month later, a couple of public disorder incidents prompted miners to amass and register their protest. In the heat of the moment, the crowd marched to the Eureka Hotel and set it alight. The arrest of three suspects for the burning of the hotel and the imposition of another government licensed 'man-hunt' led to a further mass meeting, and the demand for the sacking of the local police chief. Military reinforcements were sent to Ballarat, while political tensions escalated. At another mass meeting, miners established the Ballarat Reform League and elected digger leaders to develop a charter. In addition to calling for the cessation of the gold licence fees and the reform of Crown land laws and goldfields administration, the charter called for universal suffrage, the abolition of property ownership as a qualification for becoming a member of parliament, short-term parliaments and ballot voting. These were considered radical demands that sowed the seeds for Australian independence (Hill 2010).

The showdown between miners and government troops took place at a wooden stockade, which 1,500 miners had collectively built as a precaution against attack. On the night of 3 December 1854,

8 This was part of a communication from Hotham to Bar, 18 September 1854, Dispatch no. 112, VPRS 1085/P unit 8. 
approximately 150 miners were surrounded by 300 troops in a surprise attack. Firing into the stockade, 22 miners were killed, many more were injured and over 100 were arrested, as opposed to the seven soldiers who lost their lives.

In the immediate aftermath of the Eureka rebellion, Governor Hotham met with heavy public criticism. He set up a commission of inquiry; however, before the commission handed down its findings, 13 miners were charged with high treason. The trials began in February 1855 and, one after another, the accused were acquitted. The commission of inquiry ruled in favour of the miners in recommending the abolishment of the miners' licence fee, ${ }^{9}$ making land available for miners to purchase for house building and extending the franchise to enable diggers to be represented in parliament. Peter Lalor, a young digger who took a leading role in the Eureka Rebellion, was elected as a member of parliament for Ballarat in 1855. The miners' collective political action engendered a democratic victory oft-cited in Australian history books for establishing the foundational principles of governance in the struggle against British colonial rule.

Blainey (1964) cites official estimates that there were 30,000 adult miners in June 1852 , ballooning to 100,000 in 1855 with availability of gold supply still at accessible levels, down to the water table at roughly 30 feet. The size of mining claims in Australia were smaller than in California, such that there was a great deal of movement between sites as old sites became depleted and word travelled about new sites. Arriving at a new strike site early gave diggers a big edge.

Despite its laissez-faire capitalist context, the enduring memory of the Australian gold rush is of an egalitarian spirit, freedom and mateship of the gold diggers, culminating in their demands for democratic reform in 1854 at Ballarat's Eureka Stockade (Goodman 1994: 8). Gold was seen as a 'democratic mineral' (Bate 1999: 40). Diggers came together to protest on the basis of moral economy rights, confronting the bureaucratic demands of imperial officialdom; in so doing, they were seen to be advancing democratic nationalist demands (Goodman 1994).

9 'The licence fee has been undermined by widespread evasion, which has become a practiced and skilful art, and that its effective enforcement produced violent results ... To carry out the law in its integrity ... required a constant exercise of authority ... scenes between the police and the miners, were a daily occurrence, where mutual irritation, abuse, and gross violence would ensue ... The present system of a licence fee [should] be given up.' Report from the Commission Appointed to Inquire into Conditions in the Goldfields, Victorian Parliamentary Papers, Legislative Council, Votes and Proceedings, A76/1854-55,Vol. II (cited in Hill 2010: 190). 


\section{Probing the nature of nineteenth-century artisanal mining democracy}

Social levelling, identified with 'mateship' in Australia, and 'the great adventure of the common man' in California (McWilliams 1949, cited in Cornford 1999: 78) offered potential economic advantage to a broad spectrum of novice 'greenhorn' miners, many of whom could not have hoped to gain the same level of earnings in other occupational avenues in their home areas. However, not everyone who arrived in the goldfields achieved economic success or feelings of camaraderie. Many were frustrated by late arrival, lack of luck or ability to adapt to the new work setting. ${ }^{10}$

Above all, a sense of democracy was delimited to men of European descent. Racial and ethnic tensions intensified as the availability of gold dwindled. In the first years, men of whatever background dug side by side; however, as the gold supply dwindled and incomes stagnated or declined, rancour and discrimination set in, with hostility defrayed by individuals moving on to new strike sites (Paul 1969). The Californian artisanal mining democracy eroded as American citizens were distinguished from Europeans, Latin Americans, Chinese and Native Americans. Distrust amongst diggers was strongest against foreign-speaking miners, including the French, Chileans, Mexicans and Chinese, leading ultimately to expulsion of Mexicans and open hostility towards the Chinese (Rohrbough 1998).

By far the most marginalised participants in the gold rush were Native Americans. Before the gold rush, the territory was characterised by the native Californian population who engaged in a hunting and gathering mode of livelihood, and did not mine or value gold (Rawls 1999). In the first months of the rush, when the labour force was drawn primarily from Alta California's local population, more than half the gold diggers were Native Americans employed by Mexican rancho owners. Only a few of them dug or traded independently. However, as the old Hispanic paternalist order of agrarian semi-feudal estates disintegrated, the Native American presence faded. The incoming migrant mine population engulfed Native American land. Conflicts over land usage were an excuse to deploy US army troops and volunteer militia companies. By 1854, army

10 The historian Oscar Lewis (2007) estimated that less than 5 per cent of gold-rush miners left the goldfields with more money than when they arrived. 
expenditure on these incursions reached almost US\$1 million, with total removal and killing of the Native American population in many places (Goodman 1994). America's creed of 'manifest destiny' had taken hold at immense loss of livelihood and lives of the Native American population. ${ }^{11}$

So too, Australian artisanal mining democracy was severely delimiting. Aboriginals were marginalised. Gold was certainly not a democratic mineral for them, as they lost their land and were excluded from citizenship; thus, their grievance testimonies were not admissible in court. The Chinese miners, at times constituting as much as one-third of the diggers (Goodman 1994), were considered to be quiet and hardworking, but were subjected to derogatory treatment as foreigners, and ostracised from the camaraderie of mateship. General wariness towards the Chinese prevailed on the grounds that they were worryingly present in growing numbers and remained aloof from Christian conversion, at a time when a Christian moral discourse was omnipresent. In 1856, European diggers initiated an attack on Chinese diggers at Buckland where 750 of their tents were destroyed. Many Chinese miners returned to China, discouraged by the hostile threats of violence directed at them.

Thus, the democracy narrative of artisanal mining can only be recounted with the proviso that it was deeply flawed, not unlike Greek democracy's indifference to the rights of women and slaves. Artisanal mining democracy in California and Victoria represents an historical interlude in which artisanal miners became enmeshed in a frontier nation-building narrative. They took centre stage in a pioneering ethos associated with the countries' spatial and political frontier expansion. Moving into lowpopulation density areas where the regional state's presence was new and the state regulatory apparatus was not well established, artisanal miners had scope for occupational self-determination.

Other countries experiencing artisanal gold rushes in the nineteenth century with more established state governance were less amenable to miners' democratic self-direction. These included the Ghana gold boom of the 1870s in the British Gold Coast, which saw an influx of European

11 At the start of the gold rush in 1849, the Californian Native American population was estimated at 100,000 . By 1860 , their numbers had declined to approximately 35,000. While some died of disease, Russell Thornton is unequivocal that the largest number and most deliberate killings in the United States took place in northern California during the gold rush decade when 'case after case was recorded of Indian villages being massacred by larger or more powerful groups of Non-Indians' (Thornton 1987: 109, 201). 
expatriates intent on setting up mining companies for the pursuit of mechanised mining alongside a coastal Creole mercantile elite who were sub-leasing mining land for industrial mining from chiefs (Dumett 1998). This constellation of mechanised mining interests played a formative role in the gradual development of industrial mining in Ghana during the late nineteenth century and into the twentieth century, when Ghana became Africa's second-largest gold producer after South Africa.

Similarly, the gold rush of the late 1880s in the South African Rand virtually precluded open entry of artisanal miners. Cecil Rhodes and Alfred Beit had already established controlling interests over the Kimberly diamond fields. They were in a strong position to seize economic and political hegemony in gold production together with other key investors, and came to be known as South Africa's 'Randlords'. The comradeship of diggers was pre-empted by the Randlords' supremacy; the fact that the gold deposits were embedded in a mass of deep hard rock further contributed to artisanal miners' difficulty in getting a significant foothold (Meredith 2007). By 1888, speculative investors had established 450 gold-mining companies. Over time, the mining of deep hard rock seams, monopolised by such companies, was based on the employment of black wage labour.

\section{Twentieth- and twenty-first-century frontiers in Africa and Asia}

Moving a century forward to the twentieth and twenty-first centuries, gold certainly has not lost its lustre. The world price of gold began its ascent during the troubled years of the global oil crises of the mid-1970s, stabilising during the 1980s and early 1990s, only to scale new dizzying heights as the world plunged into economic recession in the latter $2000 \mathrm{~s}$ (Figure 2.1).

The following two country case studies drawn from Africa and Asia illustrate how national governments by default or design may have benign or indifferent policies to the presence of artisanal miners, which afford artisanal miners scope for democratic occupational self-determination, at least in the early stages of the gold rush. 


\section{\$/Troy ounce*}

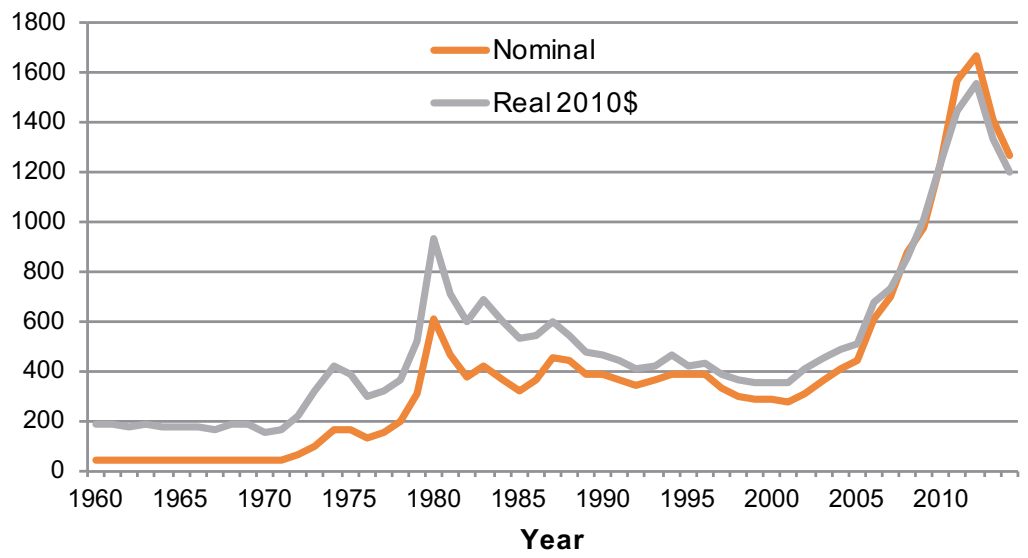

Figure 2.1: Trends in the gold price since 1960

Source: Author's graphical representation. Data source: Global Economic Monitor Commodities. Viewed at data.worldbank.org (20 June 2015).

\section{Tanzania: Evolution of artisanal mining under the blind eye of the state}

It is impossible to chart Tanzania's turn-of-the-century artisanal gold rush in terms of precise dates and names of strike sites, since the country's gold boom quietly coalesced from the early 1980s at a time of extreme duress. Following the 1979 international oil crisis, the country was economically crippled at the same time as the international price of gold was on the ascent (Figure 2.1). In need of foreign exchange, the Tanzanian Government passed the Mining Act 1979, allowing Tanzanian nationals to prospect for minerals and initiate mining activities not requiring investment in industrial machinery.

Tanzania's gold seams largely follow the bifurcation of the East African rift, forming a 'ring of gold' (Bryceson et al. 2012). Clearly farmers and ex-workers at the industrial gold mine had been aware of the rift's potential riches; however, prior to the 1979 Act they were not at liberty to engage in artisanal mining. Multiple gold discoveries started unobtrusively unfolding. With the increasing use of mobile phones in the twenty-first century, news of the gold finds spread. Gold rush fever gripped the mineral-rich regions (Jønsson and Bryceson 2009). Artisanal mining took off; yet, at the national level, there was very little 
recognition of the occupational tsunami underway. Certainly the press were not reporting gold strikes. At promising gold sites, in-migration of artisanal miners and service providers caused populations to balloon from a few hundred nearby villagers to 10,000 or more within three months. In 2011, the total population of artisanal miners throughout Tanzania was estimated at $685,000^{12}$ out of a population of 40 million. Artisanal gold production spurred urban growth within the gold-mining regions (Bryceson et al. 2012).

In the mining camp, miners and residents represented a spectrum of occupational backgrounds, education levels and classes. However, the majority migrated from rural areas and entered a multi-ethnic, cosmopolitan experience divorced from the ascriptive age and gender hierarchies of the countryside. The rank and privilege of birth, education and class were replaced with the rough and tumble of market relations and work output. Tanzanian artisanal gold-mining, as elsewhere through time, was a relatively open-entry occupation that did not necessitate a large amount of starting capital. The functional division of labour involved a pyramid of 'claim owners', who were restricted in number and usually aloof from pit production, 'pit managers', who organised the work process on behalf of the owner, and 'diggers' (Bryceson and Jønsson 2010). The division of output between these three categories varied from place to place, but usually approximated roughly a third of the hard rock mined by diggers being allocated to each category (Jønsson and Fold 2012).

While the pit managers were the 'headmen' orchestrating pit work, there was nonetheless a spirit of camaraderie and teamwork. This rested on the material fact that everyone was exposed to the physical hazards of the pit, and necessarily cognisant of the primacy of cooperation to ensure survival. So too, they were all subject to the fluctuation of mining fortunes, such that diggers could rise to become pit managers, who in turn could experience a reversal and return to being diggers when their resources to finance digging operations declined (Jønsson and Bryceson 2009; Bryceson and Jønsson 2010). In the pit, the miner had to prove himself to his workmates, showing his skill, capability to work hard and trustworthiness. Thus, in choosing to join one work team as opposed to another, these considerations prevailed over those of ethnic ties.

12 Provisional estimate according to Dr Crispin Kinabo of the Geology Department, University of Dar es Salaam. 
Claim owners by and large did not participate in gold production, and comprised only 1 per cent of the total population of artisanal miners. Yet, ironically by law, they were the only Tanzanian artisanal miners with legal mining rights. This raised a number of ambiguities and potential tensions between the state and artisanal miners. The main source of contention was the state's mediation between small- and large-scale foreign mining interests.

In a number of cases, beginning in the late 1990s, artisanal miners were told that their diggings encroached on mining company concessions (Kulindwa et al. 2003; Lange 2008). ${ }^{13}$ Artisanal miners organised political protests against the state and foreign mining firms, but they were usually forced to leave the site. In the lead-up to the opening of Tanzania's biggest industrial gold mine at Bulyanhulu in Kahama, owned by African Barrick Gold, artisanal miners claimed that 50 of them had been buried alive and killed during eviction from the concession by Tanzanian police using graders to destroy their pits. Barrick and the police denied the allegations, while various international agencies, called to give independent assessments, were divided about what had happened.

More recently in 2013, Barrick Gold's North Mara mine faced violent contestation from artisanal miners, who waged a continuous daily protest campaign against the mining company, which they blamed for the death of five artisanal miners (Hodges and Biesheuvel 2013). With these pressures weighing on their business reputation, coupled with the decline in the global gold price, Barrick Gold began a process of divesting in African Barrick Gold in Tanzania (Financial Times 2014).

In the space of three decades, Tanzania has transformed from a primarily agricultural country to a mainly mining country, measured in foreign export earnings. During the 1980s, its artisanal miners pioneered gold exploration, ${ }^{14}$ generating a regional economic boom in the country's 'ring of gold' (Bryceson et al. 2012). They benefited from the open-entry nature of artisanal mining and participated in occupational transformation that yielded more lucrative earnings than farming. In the process, they gained a new occupational identity as artisanal miners, freedom from the age and gender divisions of labour enforced by male gerontocracy

13 For example, this occurred with regards to Tom Mines in Mahenge, Barrick Mines in Bulyanhulu, North Mara Gold Mine in Tarime and East African Mines IAMGOLD in Buck Reef.

14 Artisanal miners inadvertently acted as gold prospectors for the large-scale mining companies that followed them. 
in villages and, in some cases, challenged the growing hegemony of industrial mining. This took place despite the World Bank and national government's prioritisation of foreign direct investment of large-scale industrial mining companies.

\section{Mongolia: Ambiguities of artisanal mining in a national mineral boom}

Traditionally, Mongolia's economy was comprised primarily of nomadic herding households. However, rapid deagrarianisation over the last three decades associated with the collapse of the country's Soviet-influenced commandist economy, and catastrophic weather conditions between 1997 and 2002, resulted in drastic reductions in the size of households' livestock herds. Similar to Tanzania, facing heavy debt, the Mongolian Government adhered to the World Bank's insistence on economic liberalisation and encouragement of foreign direct investment, which triggered foreign mining companies' attraction to Mongolia's gold wealth.

Artisanal mining surged as well (Cane et al. 2015). Historically, Mongolian herders had been aware of gold-rich areas, but under both the Qing dynasty of the nineteenth century and later under a repressive Soviet-style government, there were heavy penalties imposed on people who dared to engage in artisanal gold production (High and Schlesinger 2010). Furthermore, Buddhist ethics traditionally ordained a sense of harmony with the environment, which posed a moral dilemma for herders-cum-miners accustomed to adapting rather than disrupting the natural landscape (High 2008). The 'gold rush', as it became known nationally, marked a drastic rupture with the traditional economy and culture of Mongolia. The first wave of artisanal miners in the mid-1990s was primarily composed of former industrial miners who had lost their jobs when the state mining industries folded after the collapse of the Soviet-influenced government, followed by a second wave of ex-state farm workers. The third and by far the largest wave of migrants was composed of herder families reacting to the loss of livestock and general deagrarianisation (Grayson et al. 2004).

Most of the literature to date on Mongolian artisanal mining relates to its environmental impact, but very little has been written about the social and political changes underway. Mette High's (2008, 2012) insightful study of herders-cum-miners in one of the main mining regions reveals what happened at the local level within communities and households. 
In a country where people were accustomed to migrating in family units to graze their herds, migration to mining areas often involved the entire family, while others already located close to a mine site could mine parttime while continuing to tend their herd.

These tendencies contributed to widespread occupational shifts of herders, factory workers and even bureaucrats towards gold-mining, spurred by the promise of enhanced earnings from the high price of gold in the world market. ${ }^{15}$ Hence, Mongolian artisanal mining became a site of immense labour absorptive capacity. In 2013, artisanal miners numbered over 100,000 out of a national population of just 3 million, representing 20 per cent of the rural workforce (Villegas 2013). The mining sector experienced astonishing growth, generating 75 per cent of national export revenue by 2008, with artisanal mining far superseding industrial employment and output in the late 2000s (High 2008).

The legal position of artisanal miners changed under pressure from the World Bank, various foreign and local non-government agencies, and rising resource nationalism on the part of the Mongolian public and state. During the 1990s, Mongolia opened the door to foreign investment, but by the 2000s there was increasing resentment about the presence of foreign mining companies, and the feeling that Mongolian nationals were not benefiting sufficiently from the country's mineral wealth. In 2002, a draft law was proposed whereby artisanal miners were required to be licensed and organised into cooperative groups; however, local governors had the right to arbitrarily terminate artisanal miners' agreements and licences. Rising concerns about environmental destruction, the use of banned mercury and growing resource nationalism on the part of the public who resented the presence of foreign mining companies caused the government to insist on Mongolian state equity participation up to 50 per cent in all industrial mining. While the formulation of temporary regulations allowed artisanal miners some room to manoeuvre, the legality of artisanal mining remained hazy.

Although artisanal mining is identified with distress migration away from herding, wealthy households and part-time herders are active participants. High's 2008 research in Uyanga traced the effects of a gold rush that began in 1999. She observed class and ethnic diversity amongst

15 High (2008) observes that gold miners are likely to earn four times the national average salary of approximately US\$60 per month. 
the miners as well as a tendency for social levelling that encompassed women. Interestingly, returns to individuals in the miners' work groups were divided equally at the end of each workday, regardless of age and sex. This egalitarianism starkly contrasted with the social hierarchy of patriarchal herding households where women's herding and domestic work was undervalued. Nor did they receive payment on par with men during Mongolia's socialist era on the collective farms and in the towns (Lahiri-Dutt and Dondov 2016). Above all, the existence of Mongolian artisanal mining was appreciated for its role in labour absorption and poverty alleviation. People from various walks of life gained higher than average livelihoods during the gold rush. Many herders transferred their economic dependency from herding to artisanal mining (Grayson et al. 2004). Meanwhile, their enhanced purchasing power supported the expansion of a labour-generating service sector in remote areas, with the potential for small town growth.

\section{Twenty-first-century frontier democracy dissected}

The two country cases of frontier democracy reviewed here-Tanzania and Mongolia - have a similar chronology, whereby peasants and herders facing hostile conditions, be it drought and famine or, alternatively, structural adjustment austerity, found gold-mining as a lifeline or lucrative alternative. In both countries, the golden opportunity generated widespread egalitarian tendencies that crossed class, ethnic and, in Mongolia, gender boundaries.

While nineteenth-century gold rushes were characterised by discovery and excavation of gold in remote, sparsely populated regions viewed as political frontiers in the eyes of the state, by the twenty-first century, populations had become denser and state territories were generally permanently fixed. Given ample supplies of local manual labour within the country, nation-states are now far less likely to publicly encourage international in-migration of miners, in contrast to what had happened during the Californian and Victorian gold rushes. However, foreign migrants from neighbouring states can cross borders unnoticed and usually pass as natives. Artisanal miners, migrating in large numbers from within their national borders to gold rush sites, are most common.

Like nineteenth-century artisanal gold rush sites, those of the late twentieth and twenty-first century represent a spectrum of outcomes, ranging from temporary easing of artisanal mining controls to repressive policies aimed 
at actively dissuading or eliminating artisanal miners. For example, goldrush mining in West Java, triggered by the 1997 Asian financial crisis and the fall of the autocratic Suharto Government, led to an estimated 26,000 illegal artisanal miners flooding into Pongor; the composition of the migration flow reflected the legacy of insecurity from the Suharto period (Lestari 2007, 2011). Migrants from Banten Province or nearby cities aimed to occupy the most valuable sites, and formed rival gangs to achieve that end. Some of Indonesia's military generals became involved with medium-scale operations involving equipment, hiring artisanal miners or monopolising existing pits and renting them out. Artisanal miners' self-employed status was thereby compromised. Conflict between Antam mining company and the artisanal miners flared in December 1998, and intensified into the millennium. Clearly, the artisanal gold rush of the late 1990 s and early 2000s in Indonesia was far from approximating collegial occupational transformation and a democratic frontier in labour relations.

Ghana's gold rush in the 2010s has included migrants from China, neighbouring African countries and a sprinkling of other nationalities of which Russians are noteworthy, but the majority of miners are Ghanaian nationals intent on earning a livelihood. Chinese miners started being arrested in 2013, this was followed by a presidential crackdown on the local illegal artisanal galamsay miners (Levin 2013). Several military operations have been staged with the objective of eradicating their digging activities. The media demonised the galamsay, but criminalising them did not deter their presence (Hilson and Hilson 2015). Steeped in gold history, Ghana's artisanal mining context was metaphorically a bubbling cauldron of melded vested interests of small-, medium- and large-scale gold producers, in situ local communities, chiefs and regional and national governments. The ensuing contestation and conflict acted to throttle artisanal miners' individual and collective democratic voice.

\section{Conditions of existence: Gold rush frontier democracy then and now}

I have explored the dynamics of frontier democracy with respect to the numerical size and demographic composition of miners; the nature of the labour process, notably organisational aspects of the work teams, their social and political identity and coherence as a collective labour force; the material and legal aspects of mineral access; the artisanal 
mining presence vis-à-vis the state; and artisanal miners' interaction with other external agents, notably the indigenous population and corporate mining interests.

The narrative emerging from this historical review is one of remarkably similar social transformations experienced by gold rush migrant populations spanning the nineteenth to the twenty-first century, despite widely differing cultural origins of the migrants. In the nineteenth century, European populations dominated the frontier artisanal labour expansion in colonial and post-colonial North America, Australia and New Zealand, whereas the twenty-first century, with its unprecedented international gold prices (Figure 2.2), witnessed the spread of innumerable artisanal gold sites across Asia, Africa and Latin America. Regardless of migrant gold rush miners' differences in beliefs pertaining to social hierarchical order, nature and resource utilisation, most miners were likely to embark on artisanal mining with a strong sense of expediency, adopting a lifestyle of hard work and hard play, infused with an infectious sense of expectation. Artisanal miners working side by side to find and extract gold shared a common identity and ethos. Their associational ties as miners were underpinned by an innovative can-do determination and camaraderie, a 'Eureka ethos', which sometimes transgressed local social boundaries of propriety.

\section{\$lounce}

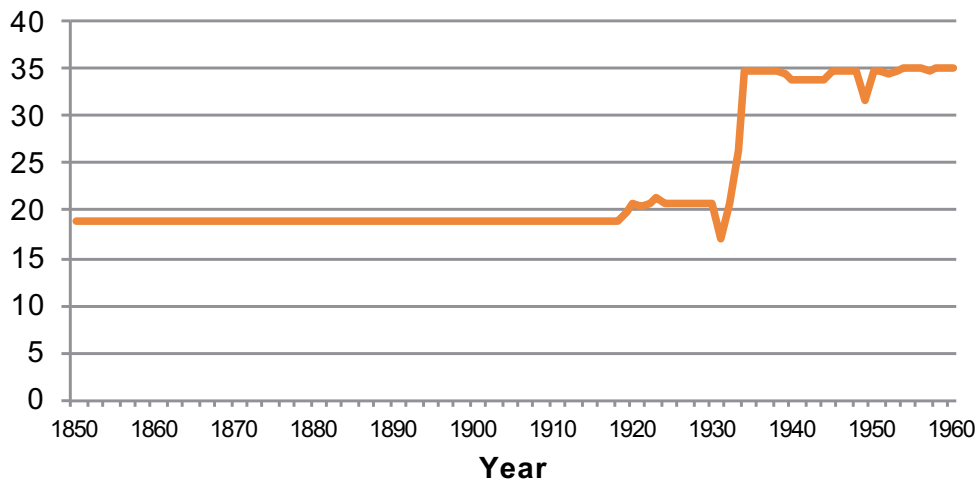

Figure 2.2: International gold prices, 1850-1960

Source: Author's graphical representation. Data source: usagold.com/reference/prices.

Curiously, during the mid-nineteenth century, public opinion and the media were highly favourable to the gold rush miners, often seeing them as pioneering role models, whereas in the twenty-first century, they tend 
to be ignored or viewed as a nuisance standing in the way of 'modern mining, as is the case in Tanzania and Mongolia. In countries with longer mineral production histories, more entrenched mining company interests and governments supporting large-scale mining, artisanal miners were usually disparaged as environmental polluters and illegal workers, subjected at times to criminalisation, as exemplified by Ghana. Yet many artisanal miners, facing a stiffening atmosphere of hostility, nonetheless found room for occupational manoeuvre in these settings, although the experience of frontier democracy largely eluded them.

A number of criteria associated with national and local governments preclude or undermine frontier democracy. First, contested local interests in land and mineral rights: given higher population densities than prevailed 150 years ago, local property interests of people with different modes of livelihood tend to be both complex and deeply entrenched. Second, mining policies are now skewed towards large-scale mining. Transnationalism of corporate industrial mining over the twentieth century has brought large-scale mining interests to the fore in far more places than ever before. The global surge in market liberalisation policies from the 1990s onwards engendered a proliferation of national and foreignowned mining companies. Third, under global economic liberalisation, increasing mutuality of interests of multinational mining corporations and national governments has evolved (Moody 2007; Campbell 2009). All three criteria appear to be more prevalent in the twenty-first century. Such circumstances stack the odds heavily against artisanal miners' activities and the emergence of frontier democracy.

Despite these obstacles, manifestations of frontier democracy have emerged in various places in the twenty-first century, but through different forms of mutuality between the state and artisanal miners. The development of frontier democracy during the nineteenth century arose in a historical period of nation-state expansion into remote geographical areas where artisanal mining proved useful to state-building agendas of governments, albeit often at the expense of the aboriginal populations.

In the twenty-first century, with national borders worldwide relatively fixed, interests of artisanal gold miners and state agents are most likely to converge when government politicians seek to win votes from the mass numbers of artisanal miners. They may also converge in the process of individual government officials or commercial middlemen seeking pecuniary gain along the gold commodity chain between local sources of 
gold supply and the foreign export of gold. For example, in Tanzania it is rumoured that most artisanal unprocessed gold is smuggled to Dubai, evading royalty payment (Fold et al. 2014). ${ }^{16}$ This kind of subterfuge in foreign exports would most likely benefit state and/or market elites in the capital city.

The duration of a gold rush tends to be short-lived, as miners using handheld artisanal implements reach a depth where they cannot proceed further without considerable capital investment in equipment. Four to six years is the norm before there is a substantive tail-off of the rush. The significance of temporality in relation to the unfolding non-renewable nature of mineral deposits, fluctuating rates of in-migration, state attempts to assert control and the availability of alternative options have altered labour patterns over the centuries. In the nineteenth-century Californian and Victorian gold rushes, it is believed that many if not most artisanal miners migrated back to their home areas as large-scale capitalised mining displaced artisanal mining. In both places, the gold rush catalysed economic diversification in services and industry, beckoning former miners, especially since many had witnessed the high returns to labour in services as the gold rush proceeded.

Perhaps the most significant and enduring difference between the nineteenth and twentieth centuries is the post-gold rush phase. In the twenty-first century, smallholder farmers find it difficult to compete with larger-scale producers and agro-industry. Many are not attracted to returning to their rural home areas, having grown accustomed to higher levels of income and a freer, non-traditional lifestyle. In the service sectors around the mining sites, formal jobs are very scarce, and the informal sector is already oversubscribed. Thus, artisanal miners are likely to try to eke out a subsistence reworking tailings-a precarious existence with low returns and high risks of falling foul of enforcement agencies of the mining companies or state. Fundamentally, artisanal miners' persistence is premised on the lack of better work options elsewhere, contrasting starkly with the nineteenth-century's industrial expansion and proliferation of urban employment that offered abundant alternative work options.

16 Given the sensitivity of the subject matter this is difficult to document, but Geenen (2015) has succeeded in providing a detailed account of the gold commodity chain for the eastern Democratic Republic of Congo. 


\section{Paradoxes of frontier democracy: From mirage, to material reality, to enduring legacy}

In exploring frontier democracy with respect to artisanal gold rush miners during the nineteenth century as opposed to now, I have conceptualised frontier democracy as the realisation of economic opportunity, class levelling, trust and cooperative interaction amongst manual labourers arising from their occupational solidarity as migrant artisanal miners and, in some cases, their engagement in collective political protest against external agents seen to be standing in the way of the manifest destiny of their search for gold.

Dumett (1998: 8) observed that gold has given rise to 'legends, exaggerations, and delusions' leading to 'myths and fantasies' through recorded history. I would add, with respect to the era of nationalismcum-globalisation spanning the mid-nineteenth century to the present, the production of artisanal gold has generated many positive economic and political labour trends followed by a clutch of paradoxical outcomes. Positively, gold-mining's accessibility to masses of people willing to work with simple handheld tools has provided employment to impressive numbers of artisanal miners; forged a strong occupational identity within a short period of time fostered by collectively experienced risktaking and hard work; and generated a democratic ethos in a number of places when and where the 'vent for democracy' is not preempted by the state, existing local vested interests in gold-mining or large-scale industrial mining.

These outcomes challenge the common belief that artisanal gold miners are necessarily overly acquisitive and irresponsible. True, the quest for El Dorado is an important motivational force underlying miners' migration over long distances, and persistence of hardship and uncertainty. But, too often, the emphasis on artisanal miners' end goal overlooks their mode of working, notably the collegial ties and occupational integrity of working together on a common occupational footing regardless of class and educational level, and their creativity in devising a modus operandi of shared work practices. It is not accidental that Fetherling (1988) called the phenomenon 'the Gold Crusades' to denote the intensity of purpose and common identity involved. Gold seekers were credited with transforming California from 'a half-tamed wilderness to a settled commonwealth' (Billington 1956: 218), while similarly gold-mining was 
viewed as altering Victoria from 'a minor pastoral settlement to the most celebrated British colony' (Serle 1963: 369). Despite moral criticism of artisanal miners by vocal segments of the population at that time, this pioneering narrative has prevailed, identifying artisanal miners with foundational democratic principles (Goodman 1994). The irony is that artisanal miners' contribution to economic and social development at present could be argued to be far more laudable than that of earlier gold rush miners, who participated in a highly 'delimited democracy' focused primarily on European settlers, at the expense of local people. Twenty-firstcentury artisanal mining has been more socially and ethnically inclusive, engaging larger numbers of the working population, mostly nationals.

It is lamentable that their contribution to egalitarian democracy has received negligible recognition, and is woefully under-recorded in terms of what they have achieved materially and culturally. Present-day artisanal miners should be encouraged to record and disseminate their stories of how they negotiated the organisation of artisanal mining, regardless of differences in class and education. Their testimony is vital to ensure appreciation of twenty-first-century artisanal mining's social significance. At the very least, artisanal mining has provided vital poverty alleviation through employment generation and on-the-job occupational training for millions in Africa and Asia. Additionally, the Eureka ethos and labour frontier democracy represent invigorating forces of change, invaluable for national rehabilitation and renewal in the present, as well as during nineteenth-century nation-building.

The final irony is that neoliberal casino capitalism has paradoxically generated the conditions for the recent boom in artisanal mining, as well as its ultimate demise. Capitalism's gold price spiral, its expanding unregulated labour markets and the ongoing process of deagrarianisation displacing millions from age-old agrarian work patterns has triggered the artisanal gold boom. Yet, these same neoliberal economic forces, combined with the natural depletion of gold at depths accessible to artisanal miners, are likely to spell the eventual eclipse of artisanal mining by large-scale global mining interests. Generally, national governments, beholden to international financial institutions' neoliberal agenda, play a central role in this process. Inevitably in the twenty-first century, smallscale producers, in whatever occupational sphere, face the Goliath of international capitalism. The democratic legacy of artisanal gold-rush mining of the late twentieth and early twenty-first centuries is too valuable for the future to be ignored, forgotten or derided. 


\section{References}

Bate, W., 1999. Victorian Gold Rushes. Victoria: The Sovereign Hill Museum Associations.

Billington, R., 1956. The Far Western Frontier 1830-1860. New York: Harper.

Blainey, G., 1964. The Rush that Never Ended: A History of Australian Mining. Melbourne: Melbourne University Press.

Brown, J.S., 1894. California Gold: An Authentic History of the First Find. Oakland: Pacific Press Company.

Bryceson, D.F., 1999. 'African Rural Labour, Income Diversification and Livelihood Approaches: A Long-term Development Perspective.' Review of African Political Economy 80: 171-89. doi. org/10.1080/03056249908704377

Bryceson, D.F., 2002. 'Multiplex Livelihoods in Rural Africa: Recasting the Terms and Conditions of Gainful Employment.' The Journal of Modern African Studies 40(1): 1-28. doi.org/10.1017/S0022278X01003792

Bryceson, D.F., 2010. 'Africa at Work: Transforming Cccupational Identity and Morality.' In D.F. Bryceson (ed.), How Africa Works: Occupational Change, Identity and Morality. Rugby: Practical Action Publishing. doi.org/10.3362/9781780440248.001

Bryceson, D.F. and S. Geenen, 2016. 'Artisanal Frontier Mining of Gold in Africa: Labour Transformation in Tanzania and the Democratic Republic of Congo.' African Affairs 115(459): 296-317. doi. org/10.1093/afraf/adv073

Bryceson, D.F. and J.B. Jønsson, 2010. 'Gold Digging Careers in Rural Africa: Small-Scale Miners' Livelihood Choices.' World Development 38(3): 379-92. doi.org/10.1016/j.worlddev.2009.09.003

Bryceson, D.F. and J.B. Jønsson, 2014. 'Mineralizing Africa and Artisanal Mining's Democratizing Influence.' In D.F. Bryceson, E. Fisher, J.B. Jønsson and R. Mwaipopo (eds), Mining and Social Transformation in Africa. London: Routledge. 
Bryceson, D.F., J.B. Jønsson, C. Kinabo and M. Shand, 2012. 'Unearthing Treasure and Trouble: Mining as an Impetus to Urbanisation in Tanzania.' In D.F. Bryceson and D. Mackinnon (eds), Mining and Urbanisation in Africa: Population, Settlement and Welfare. Special Issue of Journal of Contemporary African Studies: 631-49. doi.org/10. $1080 / 02589001.2012 .724866$

Campbell, B. (ed.), 2009. Mining in Africa: Regulation and Development. London: Pluto Press.

Cane, I., A. Schleger, S. Ali, D. Kemp, N. McIntyre, P. McKenna, A. Lechner, B. Dalaibuyan, K. Lahiri-Dutt and N. Bulovic (eds), 2015. Responsible Mining in Mongolia: Enhancing Positive Engagement. Brisbane: Centre for Social Responsibility in Mining.

Canfield, C. de L. (ed.), 1906. The Diary of a Forty-niner. San Francisco: M. Shepard Co.

Clay, K. and R. Jones, 2008. 'Migrating to Riches? Evidence from the California Gold Rush.' The Journal of Economic History 68(4): 997-1027. doi.org/10.1017/S002205070800079X

Cornford, D., 1999. 'We All Live More Like Brutes Than Humans.' In J.J. Rawls, R.J. Orsi and M. Smith-Baranzini (eds), A Golden State: Mining and Economic Development in Gold Rush California. Berkeley: University of California.

Douglass, W.A., 2002. 'The Mining Camp as Community.' In E.W. Herbert, A.B. Knapp and V.C. Pigott (eds), Social Approaches to an Industrial Past: The Archaeology and Anthropology of Mining. London: Routledge.

Dumett, R.E., 1998. El Dorado in West Africa: The Gold Mining Frontier, African Labor, and Colonial Capitalism in the Gold Coast, 1875-1900. Oxford: James Currey.

Fetherling, D., 1988. The Gold Crusades. Toronto: University of Toronto Press.

Financial Times, 2014. 'African Barrick Gold "could be independent in 12 months".' 23 September. 
Fold, N., J.B. Jønsson and P. Yankson, 2014. 'Buying into Formalisation? State Institutions and Interlocked Markets in Small-Scale Gold Mining.' Futures 62: 128-39. doi.org/10.1016/j.futures.2013.09.002

Geenen, S., 2015. African Artisanal Mining from the Inside Out: Access, Norms and Power in Congo's Gold Sector. London: Routledge.

Goodman, D., 1994. Gold Seeking: Victoria and California in the 1850s. Australia: Allen \& Unwin.

Grätz, T., 2002. 'Gold Mining Communities in Northern Benin as Semi-autonomous Social Fields.' Working Paper no. 36. Max Plank Institute for Social Anthropology.

Grätz, T., 2010. 'Gold-mining and Risk Management: A Case Study of Northern Benin.' Ethnos 68(2): 192-208. doi. org/10.1080/0014184032000097740

Grätz, T., 2013. 'The “"Frontier” Revisited: Gold Mining Camps and Mining Communities in West Africa.' Working Paper no. 10. Zentrum Moderner Orient (ZMO).

Grayson, R., T. Delgertsoo, W. Murray, B. Tumenbayar, M. Batbayar, U. Tuul, D. Bayarbat and C. Erden-Baatar, 2004. 'The People's Gold Rush in Mongolia - the Rise of the "Ninja" Phenomenon.' World Placer Journal 4: 1-112.

High, M., 2008. 'Wealth and Envy in the Mongolian Gold Mines.' Cambridge Anthropology 27(3): 1-19.

High, M., 2012. 'The Cultural Logics of Illegality: Living outside the law in the Mongolian gold mines.' In J. Dierkes (ed.), Change in Democratic Mongolia: Social Relations, Health, Mobile Pastoralism, and Mining. Leiden: E.J. Brill. doi.org/10.1163/9789004231474_013

High, M. and J. Schlesinger, 2010. 'Rulers and Rascals: The Politics of Gold in Qing Mongolian History.' Central Asian Survey 29(3): 289-304. doi.org/10.1080/02634937.2010.518008

Hill, D., 2010. The Gold Rush: The Fever that Forever Changed Australia. Australia: William Heinemann. 
Hilson, G. and A. Hilson, 2015. 'Entrepreneurship, Poverty and Sustainability: Critical Reflections on the Formalisation of Small-Scale Mining in Ghana.' Working Paper. Oxford \& London: International Growth Centre.

Hocking, G., 2006. Gold: A Pictorial History of the Australian Goldrush. Victoria: The Five Mile Press.

Hodges, J. and T. Biesheuvel, 2013. 'African Barrick Gold Sued in U.K. by Tanzanians over Death.' Bloomberg Business, 30 July. Available at www.bloomberg.com/news/articles/2013-07-29/african-barrick-goldsued-in-u-k-by-tanzanians-over-mine-deaths

Holliday, J.S., 2002. The World Rushed In: The California Gold Rush Experience. (Based on Swain's diary). Norman: University of Oklahoma Press.

Jønsson, J.B. and D.F. Bryceson, 2009. 'Rushing for Gold: Mobility and Small-Scale Mining in East Africa.' Development and Change 40(2): 249-79. doi.org/10.1111/j.1467-7660.2009.01514.x

Jønsson, J.B. and N. Fold, 2012. 'Dealing with Ambiguity: Policy and Practice Among Artisanal Gold Miners.' In D.F. Bryceson, E. Fisher, J.B. Jønsson and R. Mwaipopo (eds), Mining and Social Transformation in Africa: Mineralizing and Democratizing Trends in Artisanal Production. London: Routledge.

Keesing, N., 1967. History of the Australian Gold Rushes: By Those Who were There. Australia: Angus \& Robertson Publishers.

Kulindwa, K., O. Mashindano, F. Shechambo and J. Sosovele, 2003. Mining for Sustainable Development in Tanzania. Dar es Salaam: Dar es Salaam University Press.

Lahiri-Dutt, K. and H. Dondov, 2016. 'Informal Mining in Mongolia: Livelihood Change and Continuity in the Rangelands.' Local Environment 22(1): 126-39. doi.org/10.1080/13549839.2016.1176 012

Lange, S., 2008. 'Land Tenure and Mining in Tanzania.' CMI Report no. 2. Bergen: Chr Michelsen Institute. 
Lestari, N.I., 2007. 'Illegal Gold Mining in West Java-Can Antam's Community Development Programs Win Over Cynical Locals?' Artisanal and Small-Scale Mining in Asia-Pacific Case Study Series. Viewed at www.asmasiapacific.org (site discontinued)

Lestari, N.I., 2011. 'The Informal and Small-Scale Industry in Indonesia.' The Australian National University (PhD thesis).

Levin, D., 2013. 'Ghana’s Crackdown on Chinese Gold Miners Hits One Rural Area Hard.' New York Times, 29 June.

Lewis, O., 2007 [1949]. Sea Routes to the Gold Rush. Oakley, CA: Oakley Press.

McCone, M. and R.J. Orsi, 1999. 'Preface.' In J.J. Rawls, R.J. Orsi and M. Smith-Baranzini (eds), A Golden State: Mining and Economic Development in Gold Rush California. Berkeley: University of California.

McDowell, A.G., 2013. 'From Commons to Claims: Property Rights in the California Gold Rush.' Yale Journal of Law and the Humanities 14(1): $1-72$.

Meredith, M., 2007. Diamonds, Gold and War: The Making of South Africa. London: Pocket Books.

Moody, R., 2007. Rocks \& Hard Places: The Globalisation of Mining. London: Zed Books.

Paul, R., 1969. California Gold: The Beginning of Mining in the Far West. Lincoln: University of Nebraska Press.

Rawls, J.J., 1999. 'Introduction.' In J.J. Rawls, R.J. Orsi and M. SmithBaranzini (eds), A Golden State: Mining and Economic Development in Gold Rush California. Berkeley: University of California.

Rohrbough, M.J., 1998. Days of Gold: The California Gold Rush and the American Nation. Berkeley: University of California Press.

Royce, J., 2002 [1886]. A Study of American Character. Santa Clara: California Legacy Book.

Serle, G., 1963. The Golden Age: A History of the Colony of Victoria 1851-1861. Melbourne: Melbourne University Press. 
Street, F. J., 1851. California in 1850 Compared with What it was in 1849, and a Glimpse of its Future Destiny. Cincinnati: R.E. Edwards \& Co.

Thornton, R., 1987. American Indian Holocaust and Survival: A Population History since 1492. Norman: University of Oklahoma Press.

US Library of Congress, n.d. California as I Saw It: First Person Narratives of California's Early Years, 1849-1900. US Library of Congress digital collection. Washington DC. Available at www.memory.loc.gov

Vaught, D., 2007. After the Gold Rush: Tarnished Dreams in the Sacramento Valley. Baltimore: John Hopkins University Press.

Villegas, C., 2013. 'Ninja Miners and Rural Change in Mongolia.' Viewed at www.asm-pace-org/blog/item/itninja-miners-and-change-inmongolia.html (site discontinued)

Werthmann, K., 2000. 'Gold Rush in West Africa: The Appropriation of "Natural Resources": Non-industrial Gold Mining in South-Western Burkina Faso.' Sociologus 50(1): 90-104.

Werthmann, K., 2003. 'The President of the Gold Diggers: Sources of Power in a Gold Mine in Burkina Faso.' Ethnos 68(1): 95-111. doi. org/10.1080/0014184032000060380

Werthmann, K., 2010. “Following the Hills": Gold Mining Camps as Heterotopias.' In U. Freitag and A. von Oppen (eds), Translocality: The Study of Globalising Processes from a Southern Perspective. Leiden: E.J. Brill. doi.org/10.1163/ej.9789004181168.i-452.31 
This text is taken from Between the Plough and the Pick: Informal, artisanal and small-scale mining in the contemporary world, edited by Kuntala Lahiri-Dutt, published 2018 by ANU Press, The Australian National University, Canberra, Australia.

doi.org/10.22459/BPP.03.2018.02 